\title{
Perancangan Alat Pengangkut Sampah pada Saluran Air secara Kontinyu
}

\author{
Asep Indra Komara ${ }^{1}$, Luthfi Fattah Buchari ${ }^{2}$ \\ ${ }^{1}$ Jurusan Teknik Perancangan Manufaktur, Politeknik Manufaktur Bandung \\ ${ }^{2}$ Teknologi Rekayasa Manufaktur, Konsentrasi Teknik Rekayasa dan Pengembangan Produk, \\ Politeknik Manufaktur Bandung
}

Email: asep.indra@polman-bandung.ac.id

\begin{abstract}
Informasi Artikel: ABSTRAK
Received:

7 Agustus 2019

Accepted :

23 September 2019

Available

23 Desember 2019

Alat angkut sampah ini merupakan mesin yang digunakan untuk mengangkut sampah yang berada pada saluran air untuk mengefektifkan penanganan pengangkutan sampah, mengurangi tenaga operator, dan menghindari terpapar penyakit akibat bersentuhan langsung dengan sampah dialiran sungai. Kajian ini di lakukan pada saluran air di Kelurahan Cipaganti daerah Cihampelas. Berdasarkan hasil kajian, kebutuhan minimum kapasitas pengangkutan sampah adalah sebesar $14 \mathrm{~kg} /$ menit. Perancangan ini dimaksudkan untuk menghasilkan konstruksi dengan biaya pembuatan yang lebih murah dibanding mesin yang ada di pasaran saat ini. Metodologi perancangan yang digunakan adalah VDI 2222 dengan urutan pengerjaan secara garis besar merencana, mengkonsep, merancang, dan penyelesaian. Konstruksi yang dirancang memiliki enam fungsi bagian yaitu fungsi bagian penyangga, pengarah input, pemindah, pengarah output, penggerak, dan pembersih. Hasil kajian telah diperoleh konstruksi rancangan alat angkut sampah yang bekerja di saluran air secara kontinyu dengan kapasitas mesin mencapai 35 kg/menit dengan daya 750 Watt.
\end{abstract}

\section{Kata Kunci: \\ Design \\ Trash \\ Conveying \\ Continuous \\ Waterways}

\section{ABSTRACT}

This garbage transportation tool is a machine which is used to transport rubbish that is in the water channel to streamline the handling of garbage transportation, reduce operator power, and avoid exposure to diseases due to direct contact with river flow rubbish. This study was conducted on a water channel in the Cipaganti village of the Cihampelas area. Based on the results of the study, the minimum requirement for waste transportation capacity is $14 \mathrm{~kg}$ per minute. This design is intended to produce construction with manufacturing costs that are cheaper than the machines on the market today. The design methodology used is VDI 2222 with a sequence of work outlines planning, conceptualizing, designing, and completing. The construction is designed to have six part functions, namely the functions of the buffer, input directors, shifters, output directors, drives and cleaners. The results of the study have obtained the construction of a garbage conveyor design that works in waterways continuously with an engine capacity reaching $35 \mathrm{~kg}$ per minutes with 750 Watt power. 


\section{Pendahuluan}

Perancangan alat angkut sampah ini berawal dari adanya permasalahan yang tengah dihadapi oleh warga Kelurahan Cipaganti dengan terhambatnya arus air di saluran air akibat penumpukan sampah pada gorong-gorong saluran air. Akibat penumpukan sampah tersebut, terjadi banjir karena permukaan air di saluran air naik. Sampah-sampah yang menyumbat ini merupakan sampah bawaan dari hulu Sungai Cikapundung dan sampah dari daerah sekitar area Kelurahan Cipaganti. Saat ini solusi yang dilakukan adalah memasang wiremash di area gorong-gorong saluran air dan melakukan pengangkutan sampah dari area wiremesh oleh warga sekitar, lihat Gambar 1. Proses ini dinilai kurang efektif karena jumlah sampah yang relatif banyak, jam kerja warga yang terbatas, dan ketidakhigienisan air yang dapat membawa penyakit bagi warga setempat.

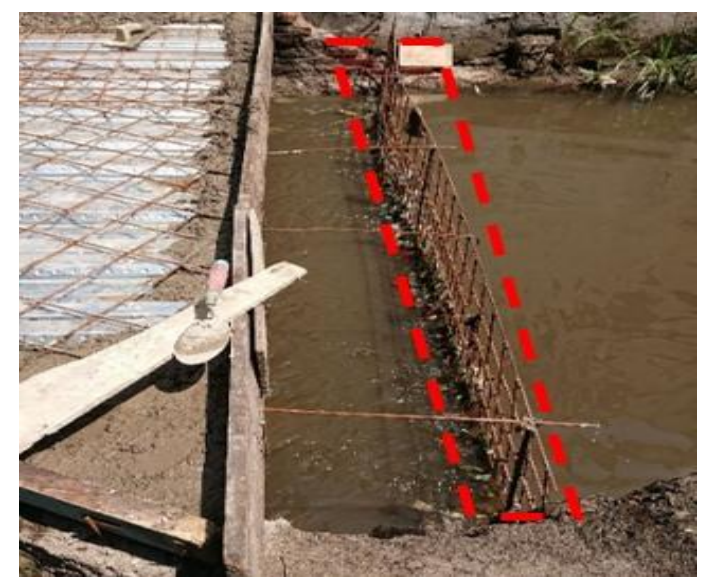

Gambar 1. Pemasangan wiremash pada saluran air

Oleh karena itu, pengadaan alat bantu angkat sampah yang bekerja secara kontinyu menjadi sangat krusial. Berbagai penelitian dan pengembangan alat atau mesin sejenis pada dasarnya sudah banyak dilakukan oleh para peneliti dan perguruan tinggi. Pada seminar [1] telah dikembangkan alat sejenis namun ditempatkan pada pintu saluran air. Pada jurnal [2] alat pengangkat sampah untuk lebar sungai dari $60 \mathrm{~cm}$ hingga $2 \mathrm{~m}$, telah berhasil diujicoba untuk mengangkat sampah organik dan non-organik dalam waktu yang singkat.

Pada jurnal [3] dikembangkan konsep alat angkat sampah dengan menggunakan dua konveyor yang digerakkan oleh motor DC, namun demikian ide pengembangan ini masih perlu disesuaikan bila ingin diterapkan untuk kelurahan cipaganti. Berbagai ide pengembangan jenis pengangkut sampah dengan menggunakan perahu (boat) dengan konsep yang dapat bergerak bahkan sudah dikontrol dengan menggunakan perangkat berteknologi juga sudah dan sedang dikembangkan seperti pada [4], [5], [6], dan [7].

Kesesuaian alat pengangkut sampah jenis ini yang cocok diterapkan di kelurahan Cipaganti pada dasarnya sudah tersedia di pasar luar negeri. Akan tetapi, harga yang ditawarkan relatif mahal yaitu sekitar $\mathrm{Rp} 118.000 .000,00$. Harga tersebut belum termasuk biaya transportasi dan pajak impor. Sebagai salah satu kontribusi yang dapat perekayasa berikan ialah dengan merancang alat bantu angkut sampah yang bekerja secara kontinyu untuk di wilayah tersebut dengan harga yang relatif murah dibanding mesin yang ada. Berdasarkan 
kajian yang dilakukan, dibutuhkan kapasitas pengangkutan minimal $14 \mathrm{~kg} / \mathrm{menit}$ untuk membersihkan saluran air dari sampah-sampah yang datang.

\section{METOde PERANCANGAN}

Metode yang digunakan dalam penyelesaian perancangan ini adalah metode perancangan VDI 2222, dengan tahapan utamanya adalah merencana, mengkonsep, merancang, dan penyelesaian.

\subsection{Tahap Merencana}

Pada tahap ini dilakukan identifikasi masalah yang tengah dihadapi oleh warga Kelurahan Cipaganti, yaitu dibutuhkan alat angkut sampah pada saluran air secara kontinyu dengan biaya yang relatif murah dibanding mesin yang ada di pasaran. Adapun dilakukannya pengumpulan data sebagai perencanaan solusi desain berupa studi pustaka, wawancara, dan observasi di lapangan. Mesin yang dirancang mengacu pada salah satu mesin yang ada di pasaran. Dari mesin ini akan diidentifikasi fungsi-fungsi dan mekanismenya dan menjadi pembanding terhadap rancangan yang akan dibuat.

\subsection{Tahap Mengkonsep}

Pada tahap ini dilakukan pembuatan daftar tuntutan sebagai acuan pembuatan rancangan. Dimana daftar tuntutan ini diperoleh berdasarkan data yang telah dikumpulkan baik dari studi lapangan maupun studi pustaka. Dari daftar tuntutan ini, akan dibuat konsep rancangan yang paling optimal terhadap penilaian aspek teknis-ekonomis.

Tabel 1. Daftar tuntutan rancangan alat pengangkut sampah

\begin{tabular}{|c|c|}
\hline Tuntutan & Keterangan \\
\hline \multicolumn{2}{|r|}{ Tuntutan Utama } \\
\hline Biaya & Semurah mungkin dan $<$ Rp 118.000 .000 \\
\hline Kapasitas & Minimal $14 \mathrm{~kg} /$ menit \\
\hline Mekanisme Kerja & Continuous \\
\hline \multicolumn{2}{|r|}{ Tuntutan Sekunder } \\
\hline $\begin{array}{l}\text { Lebar Saluran Air } \\
(\mathrm{mm})\end{array}$ & \multirow{2}{*}{ Mesin yang dirancang mampu ditempatkan pada saluran air } \\
\hline $\begin{array}{l}\text { Kedalaman Saluran Air } \\
(\mathrm{mm})\end{array}$ & \\
\hline
\end{tabular}

Tuntutan Tersier

\begin{tabular}{ll}
\hline Proses Perawatan & Perawatan standar dan dilakukan dalam jangka waktu relatif lama. \\
\hline Proses Pengoperasian & $\begin{array}{l}\text { Mudah, meminimalisir instruksi khusus dalam mengoperasikan mesin dan } \\
\text { tidak perlu ada pelatihan kepada operator. }\end{array}$ \\
\hline
\end{tabular}

Fungsi utama dari konstruksi yang dirancang adalah untuk memindahkan sampah yang berada di permukaan air di saluran irigasi menuju kontainer sampah. Untuk memudahkan mendefinisikan fungsi bagian yang dibutuhkan, salah satu caranya adalah dengan menggunakan bantuan black box seperti pada Gambar 2, dimana diuraikan kondisi input, proses, dan output dari alat angkut sampah tersebut.

Perancangan alat angkut sampah ini dilakukan dengan merujuk pada mesin yang sudah tersedia di pasaran sebagai acuan dalam merancang mesin pemindah sampah. Salah 
satunya adalah wastewater screening conveyor. Dengan memperhatikan referensi mesin tersebut, penguraian bagan fungsi dapat dipermudah. Dengan demikian konsep rancangan dapat dibuat seperti yang tampak pada Gambar 3.

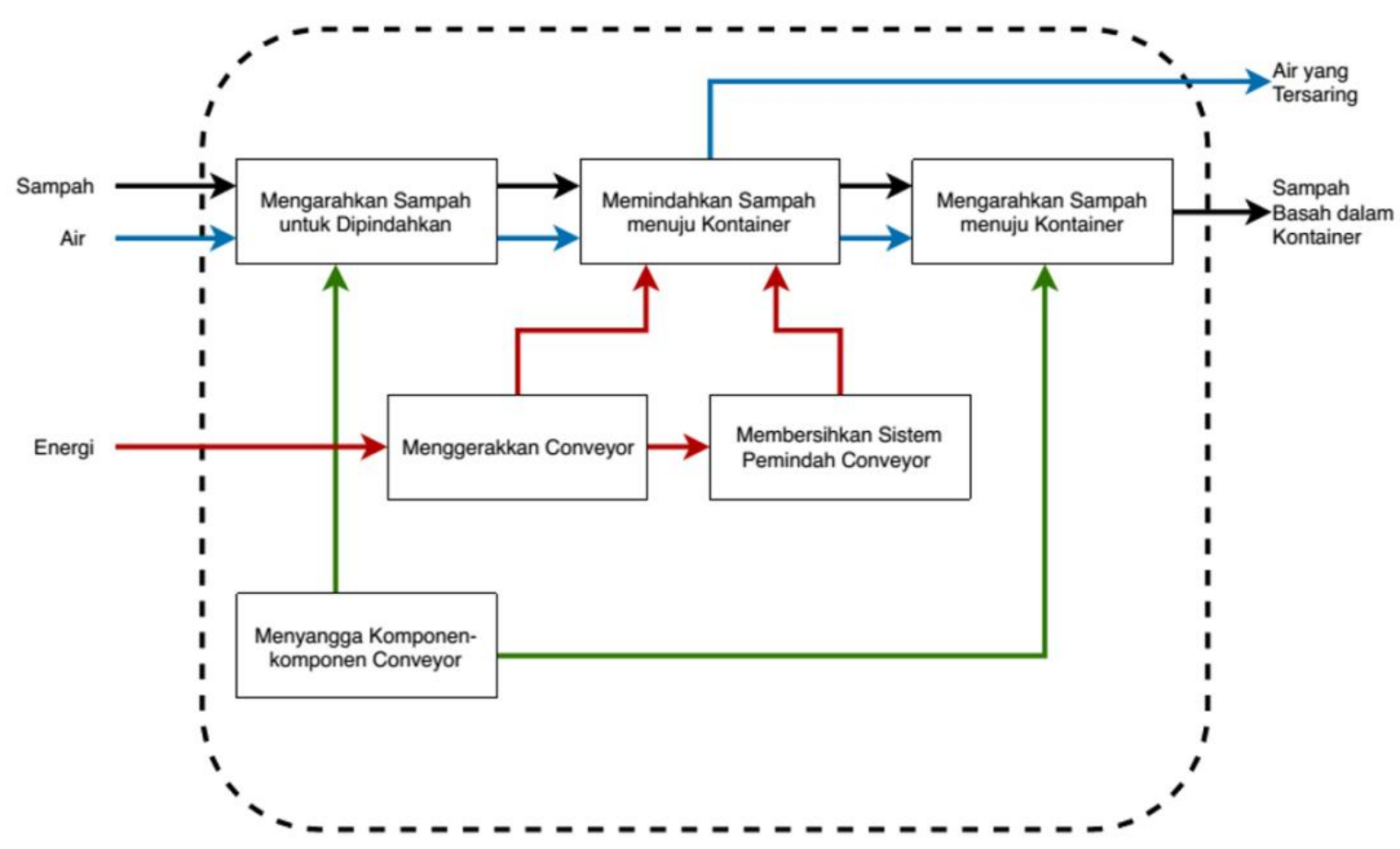

Gambar 2. Pendefinisikan fungsi bagian pada alat angkut sampah

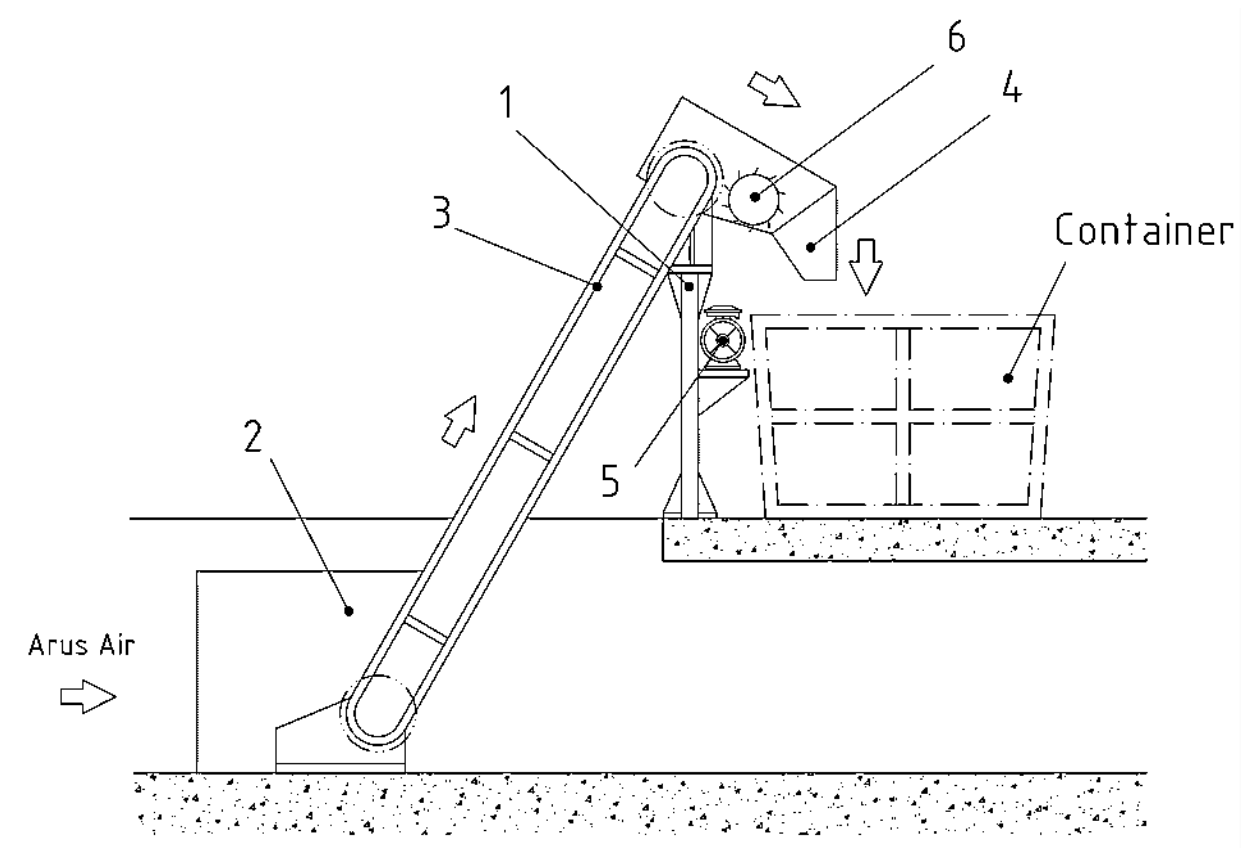

Gambar 3. Konsep rancangan alat pengangkut sampah kontinyu

Setelah semua fungsi bagian yang terdapat pada alat pengangkut sampah ini terdefinisi dan dengan mengacu pada konsep rancangan tersebut maka struktur fungsi bagian dapat disusun seperti yang terlihat pada Gambar 4. 


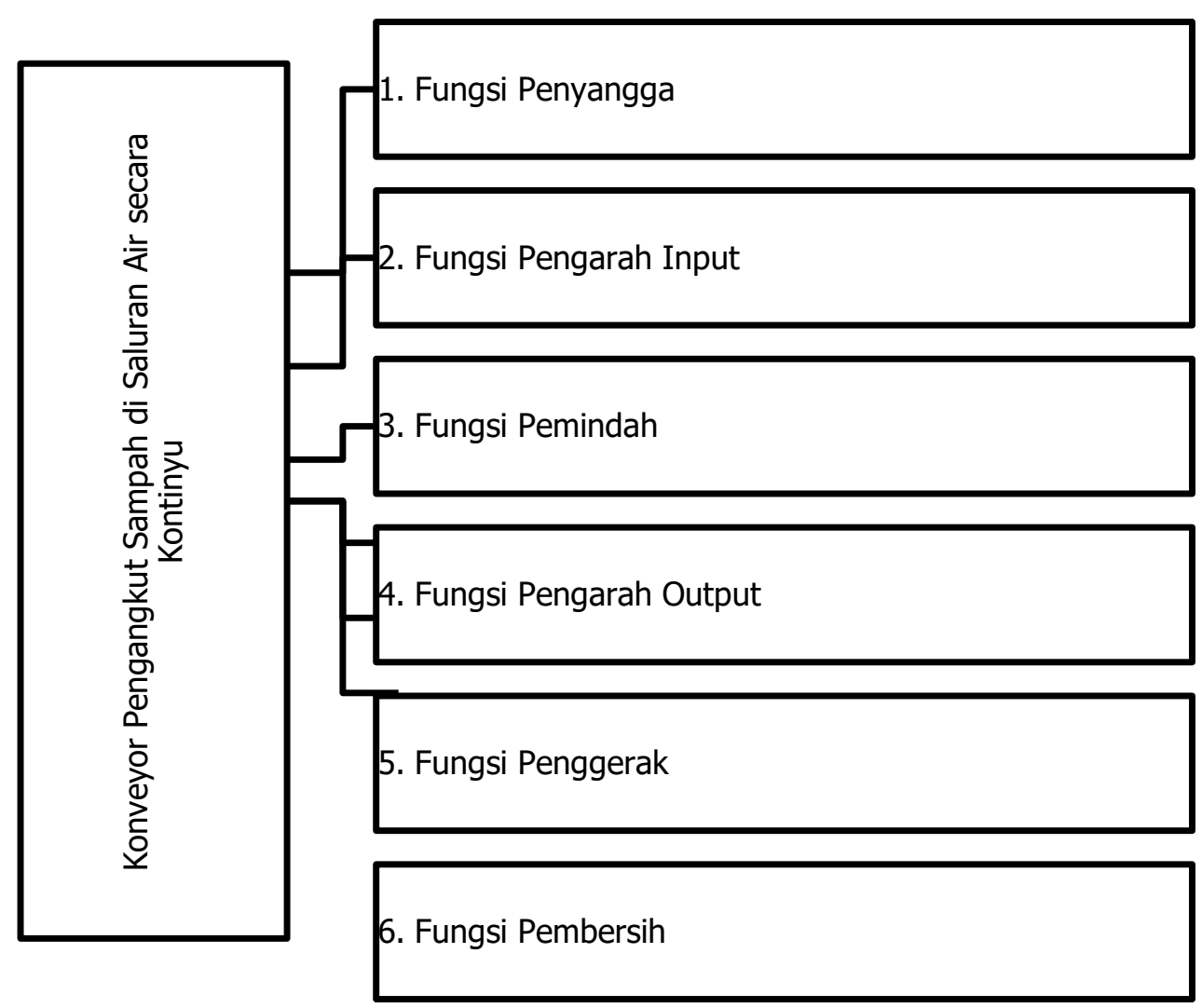

Gambar 4. Struktur fungsi bagian

Untuk mencapai hasil desain yang ideal, dibutuhkan perancangan atau penetapan alternatif komponen yang bisa memenuhi fungsi-fungsi tersebut. Diharapkan minimal dapat di cari tiga alternatif rancangan komponen sebagai pembanding. Dengan membandingkan alternatifalternatif rancangan tersebut terhadap pemenuhan aspek teknis maupun ekonomis, maka diharapkan akan diperoleh hasil rancangan yang paling optimal. Maka dari itu, perekayasa melakukan pertimbangan alternatif-alternatif fungsi bagian seperti yang dapat dilihat pada Tabel 2 berikut. 
Tabel 2. Kotak morfologi

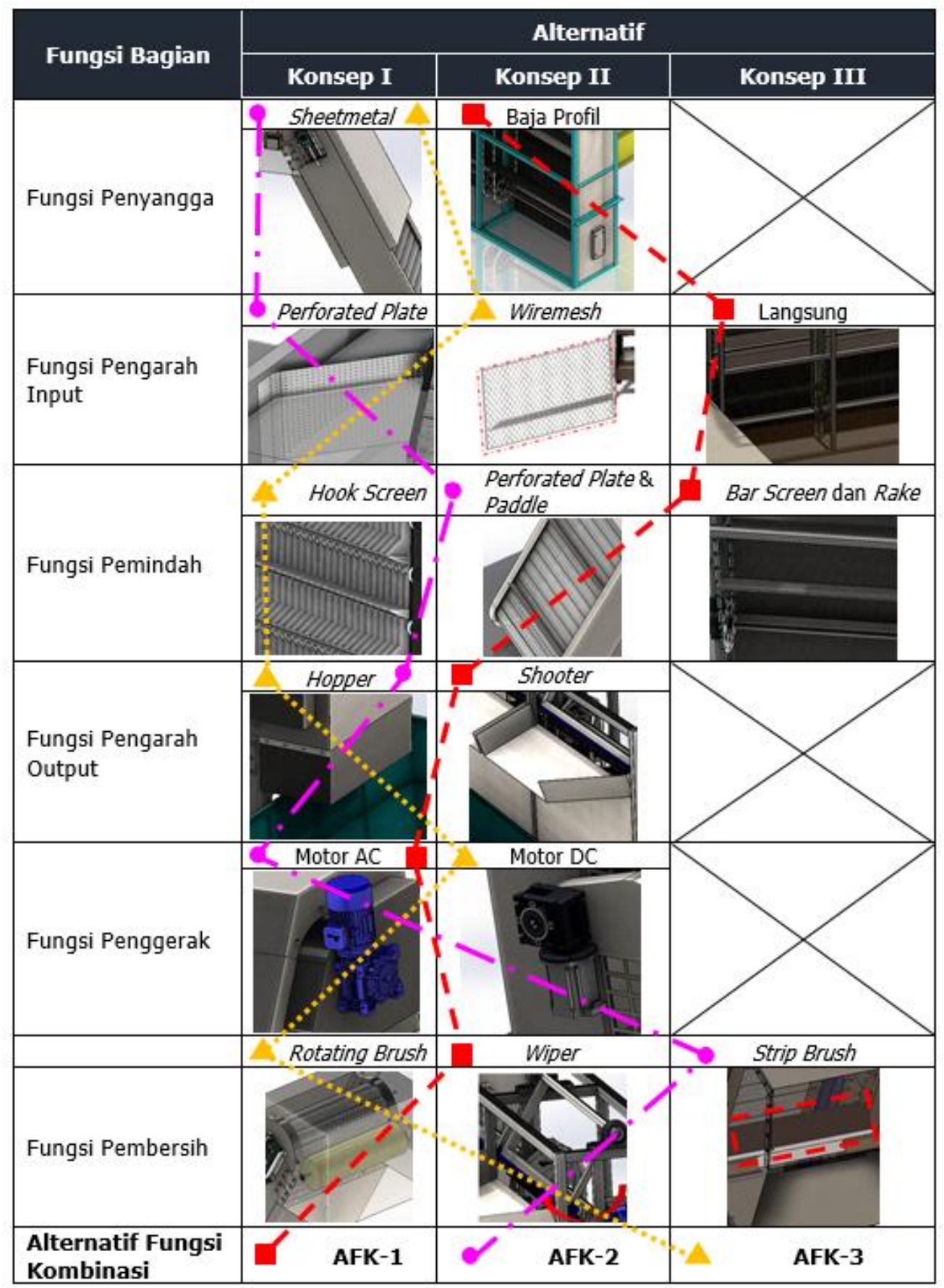

Dari Tabel kotak morfologi di atas telah dihasilkan tiga alternatif fungsi kombinasi sehingga dapat ditentukan mana alternatif fungsi yang paling baik.

\subsection{Tahap Merancang}

Berdasarkan penilaian dari aspek teknis dan aspek ekonomis, alternatif yang terpilih adalah alternatif fungsi kombinasi konsep dua (AFK-2). Lebih detailnya, alternatif variasi konsep ini menggunakan penyangga berupa sheet metal, pengarah input berupa perforated plate, pemindah berupa perforated plate dan paddle, pegarah output berupa hopper, penggerak berupa motor ac, dan pembersih berupa strip brush. 

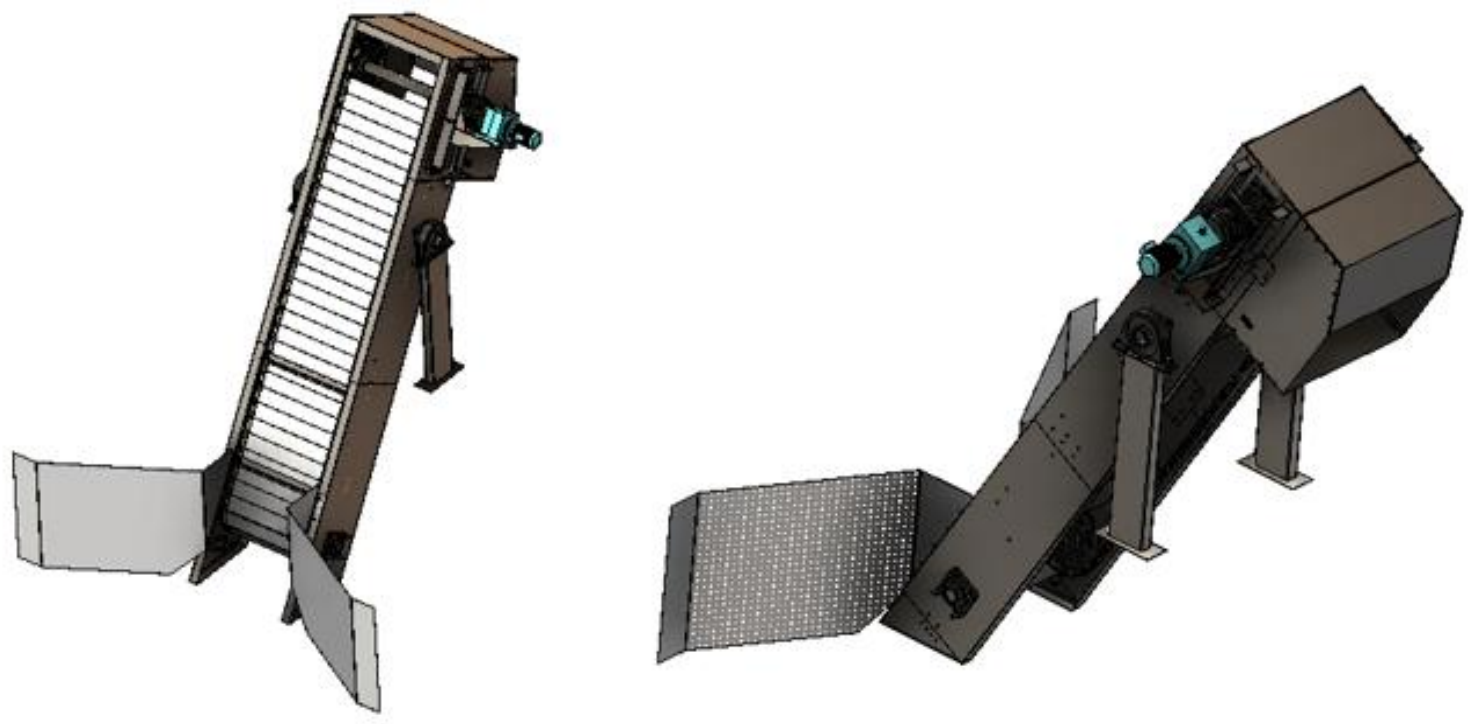

Gambar 5. Alternatif variasi konsep terpilih

\subsection{Tahap Penyelesaian}

Berikut dokumen hasil rancangan alat angkut sampah dialiran sungai yang telah dirancang.

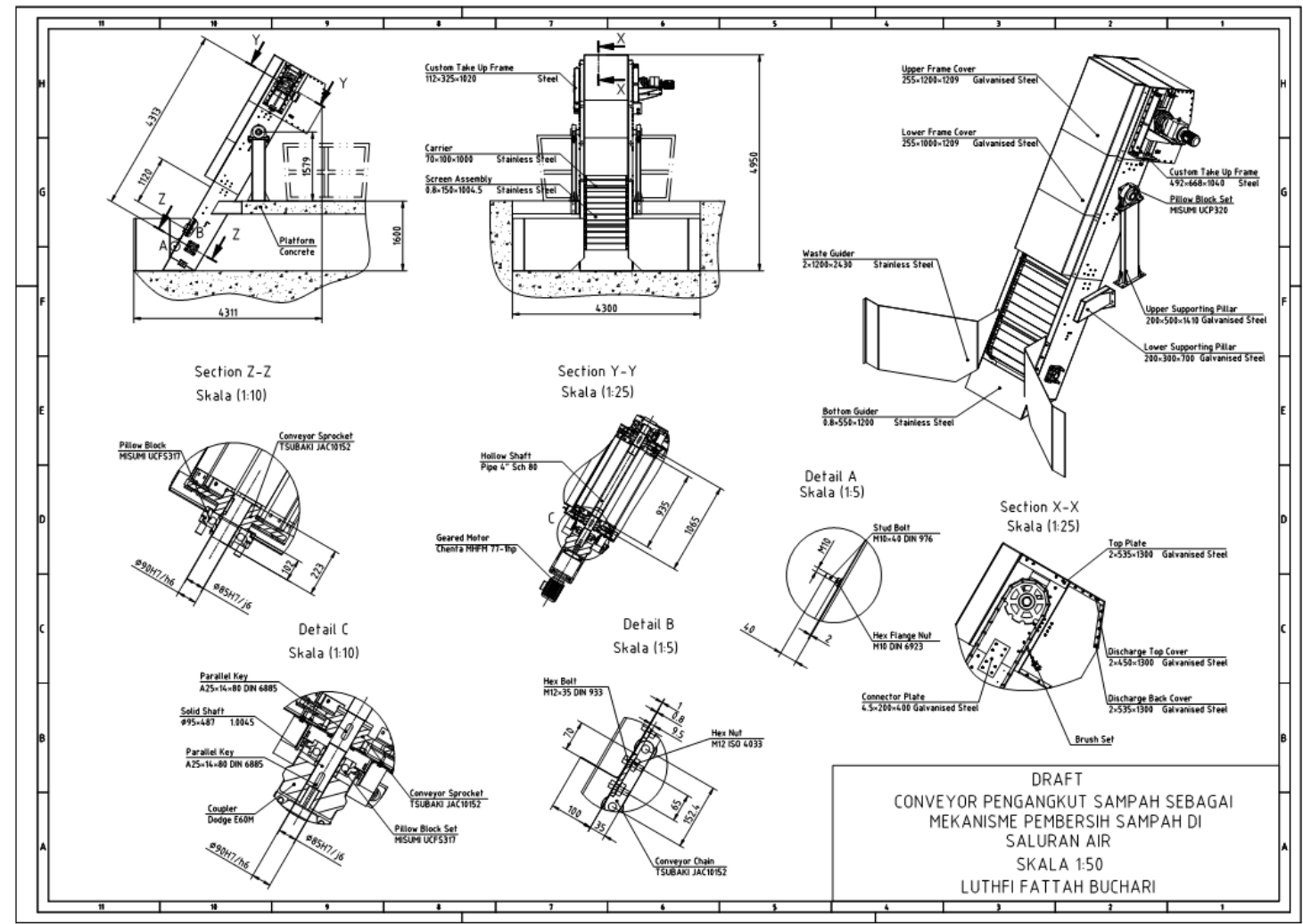

Gambar 6. Draft rancangan alat pengangkut sampah 


\section{KONTROL DAN VALIDASI RANCANGAN}

Kajian konstruksi mengenai keberhasilan fungsi dan performa komponen atau sistem rancangan perlu dilakukan melalui validasi rancangan merujuk pada geometri komponen yang digunakan agar dapat mencapai tuntutan. Kontrol dan validasi dilakukan pada (1) fungsi sistem penggerak; (2) kontrol poros penggerak; (3) umur bantalan; (4) kekuatan struktur rangka; dan (5) perhitungan kapasitas mesin.

\subsection{Sistem Penggerak}

Kebutuhan daya untuk menggerakkan sistem konveyor dihitung berdasarkan kondisi layout konveyor dan beban-beban yang bekerja pada sistem konveyor. Kondisi layout konveyor dapat dilihat pada Gambar 7.

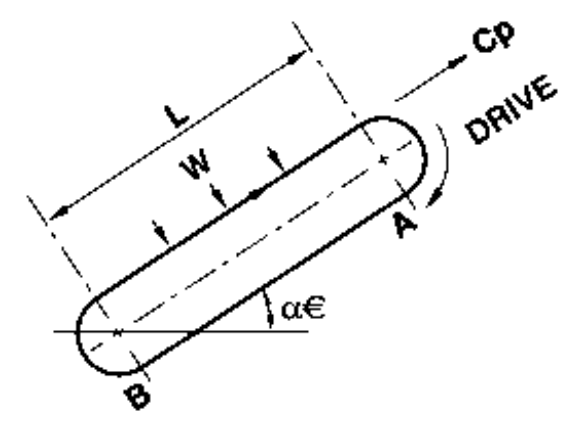

Gambar 7. Kondisi layout dan beban yang mempengaruhi sistem penggerak

Beban yang mempengaruhi dalam menentukan penggerak adalah berat total rantai per meter termasuk komponen kelengkapannya $\left(\mathrm{W}_{\mathrm{C}}\right)$, Jarak antar poros $(\mathrm{L})$, Beban yang diangkut per meter $\left(\mathrm{W}_{\mathrm{m}}\right)$, kecepatan rantai $(\mathrm{V})$, diameter sproket $(\mathrm{PCD})$, dan kondisi koefisien gesek antar komponen ( $\mu$ ). Dengan kondisi beban total sebesar $22,72 \mathrm{~kg}$ per meter dan draft konstruksi alat pengangkut sampah yang telah didesain, maka selanjutnya bisa diketahui gaya tengang rantai total $\left(C_{p}\right)$ dan kebutuhan daya $(T)$ melalui persamaan $1-4$ seperti pada [8].

$$
\begin{aligned}
& P_{B}=g \times W_{c} \times L \times \mu_{s 1}[N] \\
& C p=g \times L[(W c \times \mu s 2)+(W m \times \mu s m)]+P B+X[N] \\
& P=\frac{C_{p} \times V}{1000} \quad[k W] \\
& T=\frac{C_{p} \times P C D}{2} \quad[N m]
\end{aligned}
$$

Berdasarkan kondisi diatas, maka sumber penggerak yang dipilih adalah motor penggerak Helical Gear seri MHFM 77 dengan daya 0,75 kW dan torsi 0,524 kNm. 


\subsection{Kontrol Poros Penggerak}

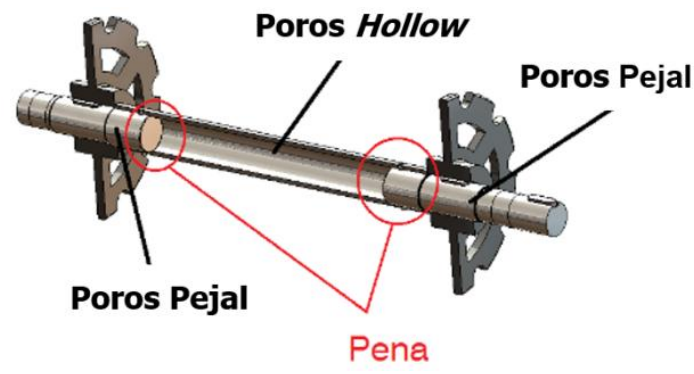

Gambar 8. Desain komponen poros penggerak

Untuk memastikan desain komponen poros penggerak dapat berfungsi dengan baik, maka perlu dilakukan kontrol terhadap kemampuan menahan beban puntir, bengkok, dan geser. Beberapa kondisi kritis yang harus diperhatikan adalah poros pejal, poros hollow, dan pena silinder.

\subsubsection{Poros Pejal}

Spesifikasi desain poros pejal dan kondisi pembebanan yang terjadi dengan mengacu pada desain konstruksi adalah sebagai berikut

- Material Poros

- Yield Strength

- Diameter Poros Kritis

- Torsi yang Terjadi

- Momen Bengkok Maks. pada poros pejal

- Gaya Geser Maks. pada poros pejal

- Momen Tahanan Puntir

- Momen Tahanan Bengkok

- Luas Penampang Geser

$$
\begin{array}{ll}
: & \text { St } 52(1.0052) \\
: & R_{e}=315 \mathrm{~N} / \mathrm{mm}^{2} \\
: & d_{P k}=90 \mathrm{~mm} \\
: & T_{P}=0.523 \mathrm{kNm} \\
: & M_{B}=500,6 \mathrm{Nm} \\
: & F_{B}=2840 \mathrm{~N} \\
: & W_{P}=140 \mathrm{~cm}^{3} \\
: & W_{B}=71,6 \mathrm{~cm}^{3} \\
: & A_{P k}=63,61 \mathrm{~cm}^{2}
\end{array}
$$

Kondisi tegangan-tegangan yang terjadi dapat dicari dengan menggunakan persamaan $5-8$ berikut seperti pada [9].

$$
\begin{gathered}
\tau_{P}=\frac{T_{P}}{W_{P}} \\
\sigma_{B}=\frac{M_{B}}{W_{B}} \\
\tau_{g}=\frac{F_{g}}{A} \\
\sigma_{v}=\sqrt{\sigma_{B}^{2}+3\left(\tau_{P}+\tau_{g}\right)^{2}}
\end{gathered}
$$

Tegangan puntir yang terjadi pada titik dimana momen bengkok maksimum adalah 3,6 $\mathrm{MPa}$, tegangan bengkok 6,9 MPa dan tegangan geser sebesar 0,44 MPa. Selanjutnya tegangan gabungan yang terjadi dikontrol dan dipastikan bahwa tegangan tersebut masih berada pada batas yang masih diizinkan, yaitu 9,97 MPa. Untuk kasus pembebanan dinamis berulang Safety factor yang dibutuhkan adalah $S_{D} 2,1$. Berdasarkan hasil kontrol perhitungan yang dilakukan maka, safety factor yang terjadi melebihi safety factor yang dibutuhkan yaitu 
31,58 sehingga dengan demikian konstruksi yang digunakan aman terhadap beban yang terjadi.

\subsubsection{Poros Hollow}

Poros hollow menggunakan pipa ukuran 4 in sch 80 . Berikut data dan spesifikasi poros hollow:

- Material Poros

- Yield Strength

- Diameter Terluar Pipa

- Diameter Dalam

- Torsi yang Terjadi

- Momen Bengkok Maks. pada Poros Pipa

- Gaya Geser Maks. pada Poros Pipa

- Momen Tahanan Puntir

- Momen Tahanan Bengkok

- Luas Penampang Geser

$$
\begin{array}{ll}
: & \text { API } 5 \mathrm{~L} \text { Grade B } \\
: & \mathrm{R}_{\mathrm{e}}=240 \mathrm{~N} / \mathrm{mm}^{2} \\
: & \mathrm{d}_{\mathrm{q}}=114,3 \mathrm{~mm} \\
: & \mathrm{d}_{\mathrm{km}}=95 \mathrm{~mm} \\
: & \mathrm{T}_{\mathrm{P}}=0,523 \mathrm{kNm} \\
: & \mathrm{M}_{\mathrm{C}}=863,9 \mathrm{Nm} \\
: & \mathrm{F}_{\mathrm{C}}=803 \mathrm{~N} \\
: & \mathrm{W}_{\mathrm{P}}=153,3 \mathrm{~cm}^{3} \\
: & \mathrm{W}_{\mathrm{B}}=84,8 \mathrm{~cm}^{3} \\
: & \mathrm{A}_{\mathrm{Pk}}=35,9 \mathrm{~cm}^{2}
\end{array}
$$

Tegangan puntir yang terjadi pada titik dimana terjadi momen bengkok maksimum adalah 3,4 MPa, tegangan bengkok $\sigma_{B} 10,18 \mathrm{MPa}$, dan tegangan geser yang terjadi $\tau_{\mathrm{g}} 0,22 \mathrm{MPa}$. Dengan demikian tegangan gabungan yang terjadi pada poros hollow sebesar 11,98 $\mathrm{MPa}$. Safety factor yang dibutuhkan adalah $\mathrm{S}_{D}=2,1$ untuk kasus pembebanan dinamis berulang. Dari hasil perhitungan, safety factor yang terjadi sebesar 15,85 melebihi safety factor yang dibutuhkan sehingga konstruksi yang digunakan aman terhadap beban yang diberikan.

\subsubsection{Pena Silinder}

Pena silinder ini berfungsi untuk menghubungkan poros hollow dengan poros pejal.

- Material Pena

- Tensile strength

- Diameter terluar pipa

- Tebal Pipa

- Diameter pipa dalam

- Torsi yang terjadi

- Faktor koreksi

- Faktor koreksi $\mathrm{K}_{\mathrm{t}}$
: $\quad 1.7131$

: $\quad \mathrm{R}_{\mathrm{m}}=1000 \mathrm{~N} / \mathrm{mm}^{2}$

: $\mathrm{d}_{\mathrm{g}}=114,3 \mathrm{~mm}$

: $s=9,65 \mathrm{~mm}$

: $\mathrm{d}_{\mathrm{w}}=95 \mathrm{~mm}$

: $\quad \mathrm{T}_{\mathrm{P}}=0,52 \mathrm{kNm}$

: $\quad \mathrm{K}_{\mathrm{A}}=1,6$

: $\quad K_{t}=0,972$

Tekanan permukaan $\left(p_{N}, p_{W}\right)$ dan tegangan geser $\left(\tau_{a}\right)$ dihitung pada pena silinder tidak boleh melebihi tegangan yang diizinkan. Kondisi ini dapat diketahui dengan persamaan 9 11 berikut seperti yang dijelaskan pada [9].

$$
\begin{gathered}
p_{N}=\frac{K_{A} \cdot T_{p}}{d \cdot s \cdot\left(d_{W}+s\right)} \leq p_{z u l} \\
p_{W}=\frac{6 \cdot K_{A} \cdot T_{p}}{d \cdot d_{w}^{2}} \leq p_{z u l} \\
\tau_{a}=\frac{4 \cdot K_{A} \cdot T_{p}}{d^{2} \cdot \pi \cdot d_{w}} \leq \tau_{a_{z u l}}
\end{gathered}
$$


Tekanan permukaan izin dan tegangan geser izin untuk pena silinder ini adalah 972,4 MPa. Kontrol tekanan permukaan di lubang hub $\left(p_{N}\right)$ yang terjadi sebesar 69,14 MPa dan tekanan permukaan di shaft bore 46,42 MPa. Sedangkan tegangan geser yang terjadi sebesar 77,98 $\mathrm{MPa}$, sehingga masih dibawah nilai tekanan permukaan dan tegangan geser izinnya. Dengan demikian dapat disimpulkan bahwa pena silinder yang digunakan aman terhadap bebanbeban yang terjadi.

\subsection{Perhitungan Umur Bantalan}

Terdapat dua jenis bantalan yang digunakan pada konstruksi mesin yaitu bantalan pengencangan dan bantalan tetap. Pada bantalan pengencangan, beban dinamis bantalan $\mathrm{C}$ $=133 \mathrm{kN}$. Dynamic bearing load P yang telah dihitung adalah $5289 \mathrm{kN}$ dan lifetime exponent $\mathrm{p}$ adalah 3 seperti pada [9]. Maka umur bearing dapat dihitung menggunakan persamaan 12 -13 berikut.

$$
\begin{aligned}
L_{10}=\left(\frac{C}{P}\right)^{p} & \\
L_{10 h} & =\frac{10^{6} \cdot L_{10}}{60 \cdot \mathrm{n}_{2}}
\end{aligned}
$$

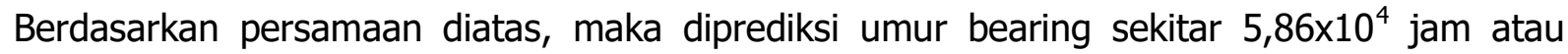
kurang lebih 6,8 tahun jika digunakan selama 24 jam sehari. Sedangkan pada bantalan tetap, beban dinamis bantalan C adalah $133 \mathrm{kN}$. Dynamic bearing load P adalah $5.43 \mathrm{kN}$ dan lifetime exponent $\mathrm{p}$ adalah 3 karena menggunakan ball bearing. Umur bearing yang dihitung adalah kurang lebih 6,15 tahun jika digunakan selama 24 jam sehari.

\subsection{Perhitungan Kekuatan Rangka}

Pada rangka ini terjadi momen bengkok maksimum dengan nilai $\mathrm{M}_{\operatorname{Max}}=10094 \mathrm{Nm}$ dan gaya geser maksimum $\mathrm{F}_{\mathrm{gMax}}=4798 \mathrm{~N}$.

- Material Rangka

- Yield Strength

- Momen Inersia

- Luas Penampang

- Jarak Terjauh dari Titik Pusat ke Ujung Penampang

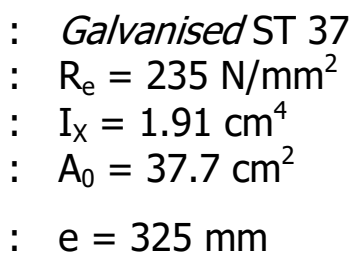

Maka tegangan bengkok dan tegangan geser yang terjadi adalah 17,141 MPa dan 1,273 $\mathrm{MPa}$. Sehingga tegangan gabungan yang terjadi adalah sebesar 17,282 MPa. Dari tegangan total dan safety factor yang diizinkan $S_{\text {Fizin }} 1,5$ maka Safety factor yang terjadi sebesar 13,598 lebih besar dari safety factor izin sehingga konstruksi aman digunakan.

\subsection{Perhitungan Kapasitas Mesin}

Setelah semua komponen dihitung dan terdefinisi, dilakukan perhitungan kapasitas yang dihasilkan dari mesin agar dapat memenuhi tuntutan yang diberikan. Kapasitas yang dibutuhkan adalah $\mathrm{Q}=14 \mathrm{~kg}$ per menit atau setara dengan $0,058 \mathrm{~m}^{3} /$ menit. Selanjutnya kontrol kapasitas mesin dilakukan dengan menggunakan persamaan 14 - 15 berikut: 


$$
\mathrm{Q}_{\mathrm{M}}=\frac{\mathrm{V}_{\text {Pembawa }}}{\mathrm{t}} \quad \mathrm{Q}_{\mathrm{M}}=\frac{\mathrm{j} \cdot \mathrm{V}_{\text {Pembawa }} \cdot \mathrm{v}_{1}}{\mathrm{~s}}
$$

Dimana,

- j : Jumlah pembawa $=10$ pcs

- Vembawa $\quad$ : Volume pembawa $=2811,9 \mathrm{~cm}^{3}$

$-\mathrm{v}_{1} \quad:$ Kecepatan motor $=0,169 \mathrm{~m} / \mathrm{s}$

- $\mathrm{s} \quad$ : Jarak antar pembawa $=1,021 \mathrm{~m}$

Maka kapasitas mesin yang dirancang akan mampu mengangkut sampah sebanyak $Q_{M} 35$ $\mathrm{kg} / \mathrm{min}$, kondisi ini telah memenuhi persyaratan yang diminta.

\subsection{Kontrol dan Validasi Menggunakan Perangkat Lunak}

Setelah dilakukan kontrol perhitungan secara teoritis, maka selajutnya dilakukan kontrol dan validasi dengan menggunakan perangkat lunak rekayasa. Simulasi FEA dilakukan dengan menggunakan software SolidWorks Simulation pada komponen kritis yaitu (1) poros hollow, (2) poros solid, dan (3) rangka. 
Perancangan Alat Pengangkut Sampah pada Saluran Air secara Kontinyu

Tabel 3. Simulasi tegangan poros hollow

- Simulasi Tegangan Poros Hollow

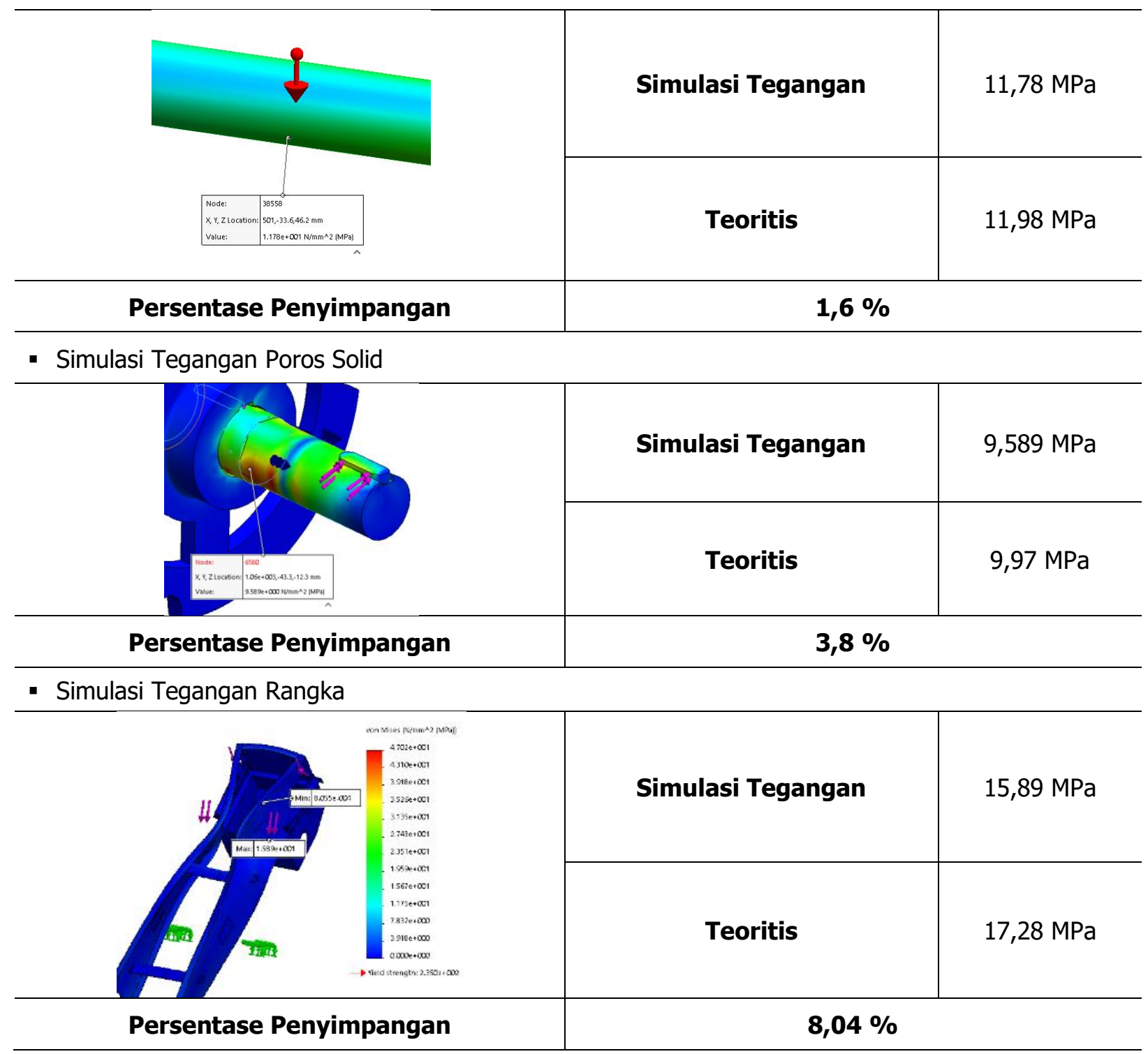

\section{ESTIMASI BIAYA}

Biaya total dihitung berdasarkan penjumlahan keseluruhan harga mulai dari raw material, komponen standar, proses pembuatan, biaya perancangan, dan overhead. Biaya ini dihitung agar dapat memenuhi tuntutan biaya pembuatan mesin. Estimasi biaya yang dibutuhkan untuk merealisasikan alat pengangkut sampah ini berkisar Rp. 86 Juta. 


\section{KESIMPULAN}

Berdasarkan kajian yang dilakukan terhadap adanya kebutuhan alat pengangkut sampah kontinyu di aliran sungai di wilayah kelurahan Cipaganti, maka dengan demikian dapat dikatakan bahwa telah dihasilkan rancangan alat pengangkut sampah yang sesuai dengan kondisi sebagai berikut:

1) Sistem pengangkut sampah yang dirancang memiliki dimensi terluar 4,3 x 4,3 x 4,9 meter, dengan daya mesin 0,75 kW dan kapasitas yang dihasilkan $35 \mathrm{~kg} / \mathrm{min}$.

2) Estimasi harga pembuatan mesin yang dirancang tersebut sebesar $\mathrm{Rp} 86,211,000.00$, dimana harga ini lebih murah dibanding harga mesin yang ada.

3) Telah diperoleh dokumentasi rancangan berupa Gambar draft sistem pengangkut sampah yang siap untuk di realisasikan.

\section{REFERENSI}

[1] S. Arif, A. Y. Aminy, "Rancang bangun alat pembersih sampah pada sungai," pada Proceeding Seminar Nasional Tahunan Teknik Mesin XI (SNTTM) \& Thermofluid IV Universitas Gadjah Mada (UGM), 2012, pp. 1353-1360.

[2] S. Riyanto, R. Kurnianto, H. S. Putra, F. E. Harianto," Rancang Bangun Inntopes (Innovation Tools Pengangkat Sampah) Pada Aliran Sungai," pada Jurnal PELITA, Volume XI, Nomor 1, April 2016, pp. 112-125.

[3] R. Prakash, J. Markose, K.P. Maneesh, N. Manohar, P. Sridharan, J. Cyriac," Automatic Trash Removal System in Water Bodies," in International Journal of Engineering Science and Computing, April 2017, pp. 6674-6678.

[4] K. V. Dhande, A. Ballade, V. S. Garde, A. S. Lahane, P. V. Boob, "Design \& Fabrication of River Cleaning System," in International Journal of Modern Trnds in Engineering and Research, 2017, pp.76-80.

[5] N.G. Jogi, A. Dambhare, K. Golekar, A. Giri, S. Take, " Efficient Lake Garbage Collector by Using Pdal Operated Boat," in International Journal of Recent Trends in Engineering \& Research, 2016, pp.327-340.

[6] D. N. Kandare, A. N. Kalel, A. S. Jamdade, G. P. Jawalw, R. K. Khanpate," Design \& Construction of River Cleaning Mechanism," in International Journal of Innovative Science and Research Technology, Volume 3, Issue 11, November 2018, pp. 428-432.

[7] S. Pawar, S. Shinde, J. Fatangare, S. Thorat, Vijaykumar," Remote Operated Floating Rivers Cleaning Machine," in International Research Journal of Engineering and Technology (IRJET), Apr 2019, pp.3344-3347.

[8] RENOLD Conveyor Chain Designer Guide. United Kingdom: RENOLD

[9] Muhs, D., Wittel, H., Jannasch, D., \& Voßiek, J. (2007). Roloff / Matek Maschinenelemente. Wiesbaden: Vieweg+Teubner. 